\title{
The Effect of Dried Blood Rumen Content Mixture (D BRCM) on Carcass Characteristics of SASSO C44 Broiler Chicks
}

\author{
Melkamu Bezabih Yitbarek \\ Department of Animal Science, College of Agriculture and Natural \\ Resources, Debre Markos University, Debre Markos, Ethiopia.

\section{Berhan Tamir} \\ Ashenafi Mengistu
}

Department of Animal Production Studies, College of Veterinary Medicine and Agriculture, Addis Ababa University, Addis Ababa, Ethiopia

doi: 10.19044/esj.2016.v12n12p166 URL:http://dx.doi.org/10.19044/esj.2016.v12n12p166

\begin{abstract}
The experiment was conducted to evaluate the effect of dried bloodrumen content mixture (DBRCM) on carcass characteristics of broiler chicks to replace soybean meal (SBM). A total of 225 unsexed day old broiler chicks (SASSO C44) were randomly distributed to five dietary treatment groups in a completely randomized design. Each treatment was replicated thrice with 15 birds per replicate. The experimental diets were formulated to contain 100\%SBM+0\%DBRCM (T1), 80\%SBM+20\% DBRCM (T2),60\%SBM+ 40\% DBRCM (T3), 40\%SBM+60\% DBRCM(T4) and $20 \% \mathrm{SBM}+80 \%$ DBRCM (T5) in 56 days of age. At the end of the experiment, two male and two female birds per replicate were used to determine carcass characteristics. The result revealed that the edible carcass yield ranged from 977.9-1159.3g. The dressing percentage based on the edible carcass weight was $63.9 \%$ (T1), $66.6 \%$ (T2), 65.4 (T3), 64.2\% (T4) and $63.1 \%$ (T5). There was no a significant difference $(\mathrm{P}>0.05)$ in both edible carcass yield and its dressing percentage. The commercial carcass weight was 937.4g (T1), 984.7g (T2), 962.0g (T3), 925.0g (T4) and 833.1g (T5) and the dressing percentage was $54.9 \%, 56.6 \%, 55.3 \%, 53.7 \%$ and $53.7 \%$ for T1, T2, T3, T4 and T5, respectively. Significant difference $(\mathrm{P}>0.05)$ was not observed in commercial carcass yield and its dressing percentage among the treatment groups. There was no a statistical marked difference $(\mathrm{P}>0.05)$ in total nonedible offal and edible offal. Females had more $(\mathrm{P}<0.05)$ breast meat than that of males. The abdominal fat and abdominal fat percentage were not significantly influenced $(\mathrm{P}>0.05)$ by a
\end{abstract}


diet containing DBRCM. However, abdominal fat and its fat percentage were higher $(\mathrm{P}<0.05)$ in females than males. Based on this result, it could be concluded that DBRCM can replace soybean meal up to $80 \%$ substitution level without any adverse effect on carcass characteristics.

Keywords: Broiler, carcass yield, DBRCM, dressing percentage, SBM

\section{Introduction}

The total poultry population in Ethiopia is estimated to be about 50.38 million, of which $96.9 \%, 0.54 \%$ and $2.56 \%$ of the total poultry were reported to be indigenous, hybrid and exotic, respectively (CSA 2013). However, the number of poultry population is large, the annual output is only 60,000 metric tonnes of meat and 40,000 metric tonnes of egg (FAO, 2013) and the per capita poultry and poultry product consumption in Ethiopia is one of the lowest in the world: $0.4 \mathrm{~kg}$ eggs and $0.6 \mathrm{~kg}$ of chicken meat per annum (FAO, 2013). Even the contribution of poultry in country's economy is only $2-3 \%$ due to different constraints (Nigusse, 1999). Among the constraints, the availability and cost of feed ingredients stand at the forefront (Melkamu, 2013). The feed cost accounts $70-75 \%$ of the total cost of production (Martinez, 1999). Most of the conventional protein sources such as peanut cake, sesame seedcake, soybean meal, and fish meal might sometimes be limited in poultry feeding due to their unavailability and costly prices (Etalem et al., 2013). For instances, about 15824.4 tonnes of soybean was produced in 2010 in Ethiopia. But the demand of the oil extracting factory is 60,000 tonnes, which covers only $40 \%$ of their production capacity and it shares only $1 \%$ of the total oil seed production (Wijands et al., 2011). Thus, using soybean for poultry ration is very expensive and not cost effective. High cost of conventional protein feedstuffs has contributed to poor productivity of many poultry farms and this has led to a shortage in the availability of animal protein to the citizenry (Adeniji and Jimoh, 2007). This situation inevitably initiates animal nutritionists and other specialists to exert their efforts in searching of cheap and locally available alternative feed ingredients that have no nutritional value to mankind for replacing the usually expensive and scarce cereal and legume grains consumed directly by humans (Onu, 2007). One of such non-conventional feedstuff, which could be of value for poultry feeding replacing soybean meal, is dried bovine blood-rumen content mixture (DBBRCM). The same source indicated that DBBRCM has a little or no cost and can be incorporated in poultry rations after appropriate processing in order to reduce production costs and alleviate pollution problems without any reported deleterious clinical effects on animal health and their performance. 
Bovine blood-rumen content mixture (BBRCM) is an abattoir (slaughter house) by-product that offers a tremendous potential as a cheap and locally available alternative feedstuff for poultry (Adeniji and Jimoh, 2007). According to CSA (2013) a cattle population in Ethiopia is 53.99 million. By considering an off-take rate of $7 \%$ for cattle (Bisrat, 2013) around 3.8 million cattle is slaughtered annually, and a recovery rate of 2.7$3.5 \mathrm{~kg}$ (DM basis) of ruminal contents (Dominguez et al., 1994) and 3-4\% of its body weight blood (Liu, 2009) per head of a slaughtered animal produced. Approximately about 133000 quintal of DM rumen content and 38 million litres of blood per annum can be produced. In the separation into plasma and blood cell fractions, $60 \%$ plasma with a solids content of $8 \%$ and $40 \%$ corpuscles with a solids content of $38 \%$ is obtained. Therefore, from $100 \mathrm{~kg}$ of blood, $4.8 \mathrm{~kg}$ of plasma powder and $15.2 \mathrm{~kg}$ corpuscle powder would be produced (Downes et al., 1987). Based on this calculation from 31 million litres of blood, 76000 quintal blood meal is produced annually in Ethiopia. If a quintal of dried rumen content and blood meal is sold by 300 and 800 Ethiopian Birr respectively, 39.9 million Birr from dried rumen content and 60.8 million Birr from blood meal can be obtained. Hence, without any use of this waste, Ethiopia lost 100.6 million Birr annually. The same to that in Debre Markos, 5000 cattle are slaughtered formally in a municipal slaughter house per annum. Accordingly, an estimated $17500 \mathrm{~kg}$ DM rumen content and 50000 litres of blood (10000 kg blood meal) can be produced annually (calculated by considering 1 cattle- $250 \mathrm{~kg}$ body weight).

These huge amounts of rumen content and blood are not utilized for animal feeding, but simply released into the environment and difficulties in disposal of such wastes. The existing system of disposing abattoir wastes is resulting in pollution not only causing problems related to odour, flies and hygiene, but surface and ground water can be polluted with pathogens and undesirable chemical compounds. Efforts have not been made yet in Ethiopia in general and in Debre Markos in particular to utilize these waste products as an alternative feed ingredient in broiler rations. The need to maximize the economic benefits and minimize the disposal problems associated with rumen content and blood, led to new interests in the investigation of these by-products for a possible use in the diets of broilers as a feed ingredient and source of protein that can replace soybean meal, an expensive feed ingredient for poultry rations in Ethiopia. Therefore, this study was conducted to evaluate the effect of feeding DBRCM on carcass characteristics of broiler chicks. 


\section{Materials and methods}

The study area

The study was conducted in Debre-Markos, Ethiopia. Debre-Markos is located at $300 \mathrm{~km}$ from Addis Ababa in Northwest of the country and 265 $\mathrm{km}$ Southeast of Bahir Dar, capital of Amhara region. The area has an altitude 2400 meter above sea level. The annual rainfall ranges from 900$1800 \mathrm{~mm}$ and a minimum and maximum temperature of the area is $7.5^{\circ} \mathrm{C}$ and $25^{\mathrm{O}} \mathrm{C}$, respectively.

\section{Collecting and processing of blood}

Fresh blood was collected in plastic container from slaughtering house immediately after the cattle is slaughtered. The blood was then transferred into a barrel and boiled to $100^{\circ} \mathrm{C}$ for 45 minutes, in order to let water evaporate and destroy pathogenic organisms. The coagulate after boiling was spread on a clean plastic sheet over the spreading table to avoid any contamination on the ground. The drying time was from 8:00 A.M to 11:00 P.M. While drying, it was stirred and turned more than four times daily so as to facilitate even drying. The material was put indoors at night to protect it from re-absorbing moisture. The drying period lasted from 3-5 days, depending on weather condition, the amount of the materials spread and frequency of turning. The particle size of the dried blood was reduced by hand crushing. Oversized dried blood was ground using a hand mortar and passed through $3 \mathrm{~mm}$ sieve size, which was similar to the size of the commercial ration.

\section{Collecting and processing of rumen content}

Fresh rumen content obtained from freshly eviscerated cattle was collected into clean containers from Debre-Markos municipality slaughtering house. The rumen was split with the aid of a sharp knife and the contents emptied into a big metal vat. The metal vat containing the rumen content was placed on burning firewood and boiled for 2 hours with intermittent stirring to prevent burning until the mixture is almost free of steam. This was done to reduce the microbial load of the rumen content. The boiled rumen content was spread on a clean plastic sheet for sun drying. The drying time was from 8:00 A.M to 11:00 P.M. While drying, it was stirred and turned more than four times daily so as to facilitate even drying. The material was put indoors at night to protect it from re-absorbing moisture. The drying period lasted from 3-4 days, depending on weather condition, the amount of the materials spread and frequency of turning. The particle size of rumen content was reduced by beating using stick and hand crushing. To uniform the particle size, oversized dried rumen content was ground using a hand mortar and 
passed through $3 \mathrm{~mm}$ sieve size, which was similar to the size of commercial ration.

\section{Mixing of dried blood and dried rumen content}

The dried blood and rumen content was taken to National veterinary institute (NVI), Bishofitu, Ethiopia for chemical analysis separately to know their chemical composition content. Then dried blood and rumen content was mixed at 1:1 ratio to produce dried blood-rumen content mixture that was used to replace soybean meal at varied levels in rations of starter and finisher phases of growth.

\section{Preparation of roasted soybean}

Soybean is locally available field crop in Debre Markos. The byproduct of oil extracted soybean meal was found in Addis Ababa and its cost was much expensive than full fat soybean regardless of the transportation cost. Due to this reason, some small scale poultry producers found in Debre Markos has used soybean as a feed ingredient for poultry ration. Even though using soybean is not economical for poultry producers. Therefore, substituting this fed ingredients by dried blood rumen content mixture was paramount important. Thus to test this substitution, sufficient amount of full fat soybean was purchased from local market in Debre Markos. All impurities were purified by the help of hand picking and wind. It was rinsed in water to clean up. The full fat soybean was roasted by metal plate around $180^{\circ} \mathrm{C}$ for 15 minutes by continuous stirring until it seems golden brownish colour to destroy the anti-nutritional components (trypsin inhibitor). Great precaution was done to avoid under and overheated. Under-heated beans have a characteristic 'nutty' taste, while over-heated beans have a much darker colour and a burnt taste. The problem with overheating is potential destruction of lysine and other heat-sensitive amino acids.

\section{Breeds of experimental birds}

Sasso is a company name established before 33 years ago by the leading French "Label Rouge" poultry producers. Sasso C44 broiler chicks is one of the most rapid growth broiler breeds which has been produced by Sasso. The bird came from a long and strict selection based on the performance. It has come from the cross breeding of a Sasso rooster and a recessive Sasso hen. SASSO C44 is a coloured chicken, alternative growth red feathers, yellow skin, shanks and feet. They are extremely resistant chicken with excellent liveability, easy to manage with a high rusticity, good carcass uniformity and provide top quality meat with excellent flavour. The birds are ideal for certified and farmer style productions. They are costeffective for producers, in the best sanitary conditions. The average live 
weight of the bird ranges from $2200 \mathrm{~g}$ to $2700 \mathrm{~g}$ and the mean body weight of male and female was $2785 \mathrm{~g}$ and 2279 gram, respectively in 56 days of growth period. The average daily gain of the bird is greater than 40 grams (SASSO C44 broiler breeds http://www.sasso.fr/best-chicken-breedsalternative-growth-for-free-range-poultry-breeding.html,retrived on 20/03/ 2016). According to Hann et al.,(2014) the average live weight of SASSO C44 broilers were 2123.5g and the mean weight of male and female was 2315g and 1932 gram, respectively in 49 days of age. The same author noted that the daily body weight gain was 46.4 gram for males and $38.6 \mathrm{~g}$ for females in 49 days of growth period.

\section{Experimental birds and their management}

Two hundred and twenty five a day old unsexed broiler chicks (SASSO C44) were randomly allocated to the pens, using a Completely Randomized Design (CRD). The experimental rooms were divided into fifteen separate pens $\left(0.12 \mathrm{~m}^{2}\right.$ /bird), of equal size $1.8 \mathrm{~m}^{2}$ by using timber and mesh wire. Before placing the experimental birds into their pens, the whole unit was cleaned, disinfected with $37 \%$ formalin two weeks prior to the introduction of chicks, allowed to dry and littered with properly dried teff (Eragrostis teff) straw used as a litter material to a depth of about $8 \mathrm{~cm}$ before the arrival of chicks. Subsequently, the necessary sanitary precautions were observed. The house was electrically heated using 200 watt bulbs per pen. The brooder temperature was maintained at about $35-32^{\circ} \mathrm{C}$ for the first 7 days of age and monitor frequently for about 3 times/day i.e. in the morning, during the day, and at night. Sufficient air exchange was also allowed, and after 7 days the temperatures was reduced gradually by $2{ }^{\circ} \mathrm{C}$ every week until the end of the experiment. Windows was opened adequately to provide natural ventilation. Clean and disinfected feeder and waterer were provided in each pen. The feeders were filled with feed twice a day at 7:308:30 AM in the morning and 5:30-6:30 PM in the evening. The drinkers were washed every day and filled with clean water. Standard vaccination schedule was done and strict sanitary measures were followed during the experimental period. Experimental chickens were vaccinated for NCD; using HB1 at $7^{\text {th }}$ day and Lasota at 21 and 45 days with drinking water and for Gumboro at day 14, 28 and 42 with drinking water. At 49 days the birds were vaccinated fowl thyphoid. Amprolium was used as a prophylactic treatment for three times (at a time $30 \mathrm{~g} / 100$ litters of water for 5 days). The experimental ration, containing dried blood rumen content mixture as replacement of soybean meal was formulated and fed for 56 days of experimental period. 


\section{Treatments and experimental rations}

All broiler chicks were individually weighed and randomly allocated to five dietary treatments replicated thrice with fifteen birds per replicate in a completely randomized design (CRD). The feed ingredients used in the formulation of the different experimental rations were maize (Zea mays), wheat middling, noug seed cake (Guizotia abyssinica), roasted soybean (Glysine max), vitamin premix, lysine, methionine, salt and limestone. The ingredients was milled to a sieve size of 3-5 $\mathrm{mm}$ and stored until required for the formulation of experimental rations.

The test diets for the starter phase (1-28 days) were formulated to be isocaloric and isonitrogenous containing $3000 \mathrm{kcal} \mathrm{ME} / \mathrm{kg}$ DM and 23\% CP , and the finisher phase (29-56 days) contain $3200 \mathrm{kcal} \mathrm{ME} / \mathrm{kg}$ and $20 \% \mathrm{CP}$ to meet the requirements of starter and finisher phases of broiler (NRC,1994). Rations were formulated based on the results of the chemical analysis of the feed ingredients, and the control diet was formulated to contain about $30 \%$ soybean meals in the total ration. Therefore, based on $30 \%$ soybean meals, the treatments contained in T1 (100\% Soybean roasted $+\quad 0 \% \quad$ DBRCM $), T 2 \quad(80 \% \quad$ Soybean roasted $+\quad 20 \%$ DBRCM), T3 (60\% Soybean roasted $+40 \%$ DBRCM), T4 (40\% Soybean roas ted+60\%DBRCM) and T5 (20\% Soybean roasted+80\%DBRCM).

\section{Measurements}

Average dry matter intake (ADMI), body weight gain, feed conversion ratio, carcass yield and mortality percentage were used to evaluate the difference between the treatment rations. Daily feed consumption was determined as the difference between the feed offered and refused on DM basis. Body weight changes were assessed every week up to the end of the experiment. Body weight gain was calculated by subtraction of the live body weight at the beginning of the week from that of the second measuring date (BWG, g/d). The average daily weight gain (ADG) was determined by dividing the average body weight gain by the number of experimental days. The mean feed conversion ratio was expressed by dividing the average DM intake by mean body weight gain (g). Mortality was recorded as it occurred and was determined for each treatment as a percentage of the total mortality at the end of the whole experiment.

\section{Evaluation of carcass characteristics}

At the end of the experiment; 60 birds (12 birds per treatment: 2 male and 2 female birds per replicate) were used to determine dressing percentage. The birds were starved for twelve hours before slaughtering. Immediately before slaughtering, each bird was weighed, killed and bled for 180 seconds. They were immersed in a bucket of hot water $\left(63^{\circ} \mathrm{C}\right)$ for approximately 120 
seconds, and de-feathered by hand plucking. The carcass was then eviscerated (removing of lower leg, head, heart, crop, pancreas, kidney, lungs, proventriculus, small intestine, large intestine, caeca and urogenital tracts) and suspended from the evisceration line and allowed to drain for 15 minutes prior to weighing. The back, two thigh, two drumsticks, two wings and breast were used to evaluate the carcass yield on a commercial basis. Dressing percentage was calculated as the proportion of carcass weight to slaughter weight multiplied by 100. Gizzard, skin and liver are edible in most places in Ethiopia and included in the edible component. These were added to the carcass weight and another version of dressing percentage was also calculated. The eviscerated carcass such as back, thighs, drumsticks, wings and breast were separated and weighed, and then their weight were divided by slaughter weight and multiplied by 100 to determine percentage weights of each component. Fat around the proventriculus and gizzard and against the abdominal wall and the cloacae was collected and weighed; and fat percentage was calculated as the proportion of slaughter weight. The giblets which include the heart, gizzard and liver were weighed and its percentage was calculated as the proportion of slaughter weight.

\section{Statistical analysis}

The experiment was arranged in completely randomized design (CRD). All collected data was subjected to analysis of variance (ANOVA) using the general linear models procedure by SAS (Version 9.2) software and for crosschecking SPSS (Version.20) software was employed. When treatment effects were found to be significant $(\mathrm{P}<0.05)$, mean separation was undertaken using Turkey HSD test. All values were calculated on a pen average basis.

\section{Results}

The chemical composition of feed ingredients used for experimental diets is presented in Table 1. The chemical composition of dried blood rumen content mixture (DBRCM) was 93.3\% DM, 7.5\%MM, 15.75\%CF, 36.93\%CP, 1.48\%EE, 1.43\%Ca, 31.64\% NFE and 2328.487 kcal ME/Kg DM. 
Table 1. Chemical composition of feed ingredients used for preparing experimental diets as DM basis

\begin{tabular}{lccccccccc}
\hline No & Feed type & DM & MM & CF & CP & EE & Ca & NFE & $\begin{array}{c}\text { Kcal ME/Kg } \\
\text { DM }\end{array}$ \\
\hline 1 & DBRCM & 93.3 & 7.5 & 15.75 & 36.93 & 1.48 & 1.43 & 31.64 & 2328.487 \\
2 & NSC & 94.6 & 8.88 & 23.35 & 38.46 & 7.27 & 2.47 & 16.64 & 1913.039 \\
3 & White Maize & 90.7 & 0.63 & 1.65 & 7.45 & 4.98 & 1.29 & 75.99 & 4049.853 \\
4 & Soybean/Roasted/ & 96.8 & 5.65 & 14.77 & 32.17 & 13.29 & 2.07 & 30.92 & 3133.357 \\
5 & Wheat Middling & 90.3 & 3.06 & 6.53 & 17.72 & 4.21 & 1.66 & 58.78 & 3475.965 \\
\hline
\end{tabular}

NOTE: DBRCM- Dried Blood Rumen Content Mixture; NSC- Noug Seed Cake; DM -Dry Matter; CP-Crude Protein; ME-Metabolizable Energy; CF-Crude Fiber; EE-Ether Extract; MM-Mineral Matter NFE-Nitrogen Free Extract; Ca-Calcium.

\section{Feed ingredients of starter and finisher ration}

The feed ingredients and chemical composition of the five dietary treatment groups of starter and finisher ration is present in Table 2.

Table 2. Proportion of ingredients used in formulating broiler starter and finisher rations, and chemical composition of the treatment groups

\begin{tabular}{|c|c|c|c|c|c|c|c|c|c|c|}
\hline \multirow{2}{*}{$\begin{array}{c}\text { Ingredients } \\
\%\end{array}$} & \multicolumn{5}{|c|}{ Starter ration } & \multicolumn{5}{|c|}{ Finisher ration } \\
\hline & T1 & T2 & T3 & T4 & T5 & T1 & T2 & T3 & T4 & T5 \\
\hline $\begin{array}{c}\text { SBM(Roasted } \\
\text { ) }\end{array}$ & 30 & 24 & 18 & 12 & 6 & 30 & 24 & 18 & 12 & 6 \\
\hline DBRCM & 0 & 6 & 12 & 18 & 24 & 0 & 6 & 12 & 18 & 24 \\
\hline Maize & 34.2 & 36.6 & 35.2 & 36.1 & 36.2 & 40.7 & 42.2 & 43.2 & 45.5 & 46.0 \\
\hline NSC & 24.4 & 24.7 & 21.8 & 21.5 & 20.6 & 13.8 & 12.5 & 12.4 & 11.7 & 9.9 \\
\hline $\begin{array}{l}\text { Wheat } \\
\text { middling }\end{array}$ & 8.8 & 6.1 & 10.4 & 9.8 & 10.6 & 12.7 & 12.7 & 11.8 & 10.2 & 11.5 \\
\hline Limestone & 1.2 & 1.2 & 1.2 & 1.2 & 1.2 & 1.2 & 1.2 & 1.2 & 1.2 & 1.2 \\
\hline $\begin{array}{l}\text { Vitamin } \\
\text { premix }\end{array}$ & 0.5 & 0.5 & 0.5 & 0.5 & 0.5 & 0.5 & 0.5 & 0.5 & 0.5 & 0.5 \\
\hline Salt & 0.5 & 0.5 & 0.5 & 0.5 & 0.5 & 0.5 & 0.5 & 0.5 & 0.5 & 0.5 \\
\hline Lysine & 0.2 & 0.2 & 0.2 & 0.2 & 0.2 & 0.2 & 0.2 & 0.2 & 0.2 & 0.2 \\
\hline Methionine & 0.2 & 0.2 & 0.2 & 0.2 & 0.2 & 0.2 & 0.2 & 0.2 & 0.2 & 0.2 \\
\hline Total & 100 & 100 & 100 & 100 & 100 & 100 & 100 & 100 & 100 & 100 \\
\hline DM (\%) & 90 & 90 & 91 & 90 & 92 & 90.4 & 90.3 & 90.1 & 90.6 & 90.2 \\
\hline CP (\% DM) & 23.1 & 23.2 & 23.1 & 23.2 & 23.3 & 20.2 & 20.1 & 20.3 & 20.2 & 20.1 \\
\hline ME(kcal/KgD & 3097. & 3058. & 3047. & 3009. & 2975. & 3293. & 3281. & 3240. & 3216. & 3198. \\
\hline M) & 7 & 5 & 5 & 1 & 4 & 7 & 3 & 3 & 2 & 9 \\
\hline CF (\% DM) & 5.2 & 5.1 & 5.4 & 5.3 & 5.1 & 6.4 & 6.2 & 6.1 & 6.3 & 6.2 \\
\hline MM (\% DM) & 8.5 & 8.6 & 8.4 & 8.3 & 8.5 & 9.3 & 9.6 & 9.5 & 9.3 & 9.4 \\
\hline EE (\% DM) & 5.4 & 5.2 & 5.3 & 5.1 & 5.4 & 5.6 & 5.5 & 5.4 & 5.3 & 5.2 \\
\hline NFE (\% DM) & 57.8 & 57.9 & 57.8 & 58.1 & 57.7 & 58.5 & 58.6 & 58.7 & 58.9 & 59.1 \\
\hline Ca (\% DM) & 1.2 & 1.1 & 1.3 & 1.4 & 1.2 & 0.84 & 0.82 & 0.86 & 0.85 & 0.81 \\
\hline
\end{tabular}

NOTE:SBM=soybean meal; DBRCM=Dried Blood Rumen Content Mixture;NSC = Noug SeedCake; $T$ $1=0 \% D B R C M+100 \% S B M, T 2=20 \% D B R C M+80 \% S B M ; T 3=40 \% D B R C M+60 \% S B M ; T 4=60 \% D B R C$ $M+40 \% S B ; T 5=80 \% D B R C M+20 \% S B M ; D M=$ Dry Matter; $C P=$ Crude Protein; $M E=$ Metabolizable Energy; $C F=$ Crude Fiber; EE=Ether Extract; $M M=$ Mineral Matter NFE=Nitrogen Free Extract; $C a=$ Calcium. Vitamin premix $=25 \mathrm{~kg}$ Broiler premix contains, Vitamin A 1000000 IU, Vitamin D3 200000 IU. Vitamin E 1000 mg, Vitamin K3 225 mg, Vitamin B1 125 mg, Vitamin B2 500 mg, Vitamin B3 1375 mg, Vitamin B6 125mg, Vitamin B12 2 mg, Vitamin PP (niacin) 4, 000 mg, Folic Acid, $100 \mathrm{mg}$, choline chloride 37,500 mg, Calcium $29.7 \%$, Iron $0.4 \%$, Copper $0.05 \%$. Manganese $0.6 \%$, Zinc $0.7 \%$, Iodine $0.01 \%$ Selenium $0.004 \%$ 


\section{Dry matter intake, body weight change, feed conversion ratio and mortality rate of SASSO C44 Boiler chicks}

Dry matter intake, body weight change, feed conversion ratio and mortality rate of SASSO C44 broiler chicks fed a diet containing dried blood rumen content mixture as a replacement of soybean meal for starter phase (1-28days), finisher phases (29-56days) and the entire experimental period (1-56days) is presented in Table 3 . When birds fed a diet containing DBRCM had no significant difference $(\mathrm{P}<0.05)$ in daily $\mathrm{DM}$ intake among the treatment groups in starter phase. However, the lowest $(\mathrm{P}<0.05) \mathrm{DM}$ intake was observed birds fed on 80\% DBRCM (T5) compared with other treatment groups in finisher and the whole growth period. The lowest $(\mathrm{P}<0.05)$ body weight gain was observed when birds fed a diet containing 80\% DBRCM in starter phase. Statistically there was no a significant difference $(\mathrm{P}>0.05)$ in body weight gain among dietary treatment groups in both finisher and the entire experimental period. There was no any significant difference $(\mathrm{P}>0.05)$ in FCR through starter, finisher and entire experimental period among the treatment groups. Significant difference ( $\mathrm{P}>0.05$ ) was not observed in mortality rate in 56 days growth period of birds among the treatment groups.

Table 3. Dry matter intake, body weight change, feed conversion ratio and mortality rate of SASSO C44 broiler chicks during starter phase (1-28 days), finisher phase (29-56 days) and enter experiment (1-56 days)

\begin{tabular}{|c|c|c|c|c|c|c|c|}
\hline \multirow[t]{2}{*}{ Parameters } & \multicolumn{7}{|c|}{ Experimental Diets } \\
\hline & T1 & T2 & T3 & T4 & $\mathbf{T 5}$ & SEM & P-value \\
\hline \multicolumn{8}{|l|}{ Starter Phase } \\
\hline $\begin{array}{c}\text { Mean daily DM } \\
\text { intake (g/bird) }\end{array}$ & 40.4 & 39.9 & 40.3 & 38.6 & 38.5 & 0.282 & 0.051 \\
\hline $\begin{array}{l}\text { Mean total DM } \\
\text { intake (g/bird) }\end{array}$ & $1130.9^{\mathrm{a}}$ & $1117.6^{\mathrm{ab}}$ & $1128.6^{\mathrm{ab}}$ & $1081.5^{\mathrm{ab}}$ & $1076.6^{\mathrm{b}}$ & 7.907 & 0.047 \\
\hline $\begin{array}{c}\text { Initial } \\
\text { bodyweight(g) }\end{array}$ & $41.5^{\mathrm{a}}$ & $41.2^{\mathrm{a}}$ & $41.3^{\mathrm{a}}$ & $41.0^{\mathrm{a}}$ & $41.3^{\mathrm{a}}$ & 0.406 & 0.998 \\
\hline $\begin{array}{l}\text { Mean final body } \\
\text { weight(g) }\end{array}$ & $772.4^{\mathrm{a}}$ & $768.8^{\mathrm{ab}}$ & $729.4^{\mathrm{ab}}$ & $753.8^{\mathrm{ab}}$ & $696.3^{\mathrm{b}}$ & 10.451 & 0.034 \\
\hline $\begin{array}{c}\text { Mean daily } \\
\text { weight } \\
\text { gain(g/bird) }\end{array}$ & $26.1^{\mathrm{a}}$ & $26.0^{\mathrm{ab}}$ & $24.6^{\mathrm{ab}}$ & $25.5^{\mathrm{ab}}$ & $23.4^{\mathrm{b}}$ & 0.374 & 0.033 \\
\hline $\begin{array}{l}\text { Mean total } \\
\text { gain(g) }\end{array}$ & $730.9^{\mathrm{a}}$ & $727.7^{\mathrm{ab}}$ & $688.1^{\mathrm{ab}}$ & $712.8^{\mathrm{ab}}$ & $655.1^{\mathrm{b}}$ & 10.474 & 0.033 \\
\hline $\begin{array}{l}\text { FCR (g DMI I/g } \\
\text { gain) }\end{array}$ & $1.5^{\mathrm{a}}$ & $1.5^{\mathrm{a}}$ & $1.6^{\mathrm{a}}$ & $1.5^{\mathrm{a}}$ & $1.6^{\mathrm{a}}$ & 0.020 & 0.153 \\
\hline \multicolumn{8}{|l|}{ Finisher phase } \\
\hline $\begin{array}{l}\text { Mean daily DM } \\
\text { intake (g/bird) }\end{array}$ & $116.2^{\mathrm{a}}$ & $116.4^{\mathrm{a}}$ & $119.1^{\mathrm{a}}$ & $116.9^{\mathrm{a}}$ & $111.8^{\mathrm{b}}$ & 0.680 & 0.001 \\
\hline $\begin{array}{c}\text { Mean total DM } \\
\text { intake (g/bird) }\end{array}$ & $3253.4^{\mathrm{a}}$ & $3259.6^{\mathrm{a}}$ & $3333.7^{\mathrm{a}}$ & $3272.6^{\mathrm{a}}$ & $3130.7^{\mathrm{b}}$ & 19.093 & 0.001 \\
\hline $\begin{array}{c}\text { Initial } \\
\text { bodyweight(g) }\end{array}$ & $772.4^{\mathrm{a}}$ & $768.8^{\mathrm{ab}}$ & $729.4^{\mathrm{ab}}$ & $753.8^{\mathrm{ab}}$ & $696.3^{\mathrm{b}}$ & 10.451 & 0.034 \\
\hline $\begin{array}{l}\text { Mean final body } \\
\text { weight(g) }\end{array}$ & $1713.4^{\mathrm{a}}$ & $1783.1^{\mathrm{a}}$ & $1811.3^{\mathrm{a}}$ & $1773.7^{\mathrm{a}}$ & $1521.1^{\mathrm{a}}$ & 41.612 & 0.203 \\
\hline $\begin{array}{c}\text { Mean daily } \\
\text { weight }\end{array}$ & $33.6^{\mathrm{a}}$ & $36.2^{\mathrm{a}}$ & $38.6^{\mathrm{a}}$ & $36.4^{\mathrm{a}}$ & $29.5^{\mathrm{a}}$ & 1.414 & 0.363 \\
\hline
\end{tabular}




\begin{tabular}{|c|c|c|c|c|c|c|c|}
\hline $\begin{array}{c}\text { gain }(\mathrm{g} / \mathrm{bird}) \\
\text { Mean total } \\
\text { gain(g) }\end{array}$ & $941.0^{\mathrm{a}}$ & $1014.3^{\mathrm{a}}$ & $1081.9^{\mathrm{a}}$ & $1019.9^{\mathrm{a}}$ & $824.8^{\mathrm{a}}$ & 39.604 & 0.360 \\
\hline $\begin{array}{l}\text { FCR (g DM I/g } \\
\text { gain) }\end{array}$ & $3.5^{\mathrm{a}}$ & $3.4^{\mathrm{a}}$ & $3.1^{\mathrm{a}}$ & $3.2^{\mathrm{a}}$ & $3.8^{\mathrm{a}}$ & 0.125 & 0.513 \\
\hline \multicolumn{8}{|l|}{$\begin{array}{c}\text { Entire } \\
\text { Experimental } \\
\text { Period }\end{array}$} \\
\hline $\begin{array}{l}\text { Mean } \\
\text { daily DM } \\
\text { intake } \\
\text { (g/bird) }\end{array}$ & $\begin{array}{l}79 . \\
0^{\mathrm{a}}\end{array}$ & $\begin{array}{l}78 . \\
9^{a}\end{array}$ & $\begin{array}{l}80 . \\
4^{\mathrm{a}}\end{array}$ & $\begin{array}{l}78 . \\
5^{\mathrm{ab}}\end{array}$ & $\begin{array}{l}75 . \\
8^{\mathrm{b}}\end{array}$ & $\begin{array}{l}0.4 \\
43\end{array}$ & $\begin{array}{c}0 . \\
00 \\
4\end{array}$ \\
\hline Mean & 44 & 44 & 45 & 43 & 424 & 24. & 0 . \\
\hline total DM & 24. & 17. & 02. & 92. & $5.8^{\mathrm{b}}$ & 78 & 00 \\
\hline $\begin{array}{l}\text { intake } \\
\text { (g/bird) }\end{array}$ & $6^{a}$ & $1^{\mathrm{a}}$ & $5^{a}$ & $7^{\mathrm{ab}}$ & & 0 & 5 \\
\hline Initial & 41. & 41. & 41. & 41. & 41. & 0.4 & 0 . \\
\hline $\begin{array}{l}\text { bodywei } \\
\text { ght(g) }\end{array}$ & $5^{\mathrm{a}}$ & $2^{\mathrm{a}}$ & $3^{\mathrm{a}}$ & $0^{\mathrm{a}}$ & $3^{\mathrm{a}}$ & 07 & $\begin{array}{c}99 \\
8\end{array}$ \\
\hline Mean & 17 & 17 & 18 & 17 & 152 & 41. & 0. \\
\hline final & 13. & 83. & 11. & 73. & $1.1^{\mathrm{a}}$ & 61 & 20 \\
\hline $\begin{array}{c}\text { body } \\
\text { weight(g) }\end{array}$ & $4^{\mathrm{a}}$ & $1^{\mathrm{a}}$ & $3^{a}$ & $7^{\mathrm{a}}$ & & 3 & 3 \\
\hline Mean & 29. & 31. & 31. & 31. & 26. & 0.7 & 0. \\
\hline $\begin{array}{c}\text { daily } \\
\text { weight } \\
\text { gain(g/bi } \\
\text { rd) }\end{array}$ & $9^{a}$ & $1^{\mathrm{a}}$ & $6^{\mathrm{a}}$ & $0^{a}$ & $4^{\mathrm{a}}$ & 45 & $\begin{array}{c}20 \\
3\end{array}$ \\
\hline Mean & 16 & 17 & 17 & 17 & 147 & 41. & 0 . \\
\hline total & 71. & 41. & 70. & 32. & $9.9^{\mathrm{a}}$ & 74 & 20 \\
\hline gain(g) & $9^{a}$ & $9^{a}$ & $0^{\mathrm{a}}$ & $6^{a}$ & & 1 & 5 \\
\hline Mortality & 0.7 & 0.0 & 0.3 & 0.7 & $1.0^{\mathrm{a}}$ & 0.1 & 0. \\
\hline rate (\%) & $a$ & & & $\mathrm{a}$ & & 33 & $\begin{array}{c}21 \\
2\end{array}$ \\
\hline $\begin{array}{c}\text { FCR } \\
\text { (gDMI } \\
\text { I/g gain) }\end{array}$ & 2.7 & 2.6 & 2.6 & 2.5 & $2.9^{\mathrm{a}}$ & $\begin{array}{l}0.0 \\
58\end{array}$ & $\begin{array}{c}0 . \\
46 \\
5\end{array}$ \\
\hline
\end{tabular}

Means with a different superscript in a row are significantly different $(P<0.05)$;DMI-Dry Matter Intake; g-gram; FCR-Feed Conversion Ratio; SEM-Standard Error of the Mean;T1-0\%DBRCM+100\%SBM Roasted; T2-20\% DBRCM +80\%SBM Roasted; T3- 40\% DBRCM +60\%SBM Roasted; T4-60\% DBRCM + 40\% SBM Roasted; T5-80\% DBRCM+20\%SBM Roasted

\section{Carcass characteristics of broilers}

The carcass characteristics of birds fed different levels of DBRCM are presented in Table 4 . The slaughter weight of birds fed in different levels of dietary treatments ranged from 1550.2-1736.8g. There was no a significant difference $(\mathrm{P}>0.05)$ in slaughtering weight among the treatment groups. The edible carcass yield was $1091.6 \mathrm{~g}, 1159.3 \mathrm{~g}, 1135.5 \mathrm{~g}, 1104.7 \mathrm{~g}$ and 977.9g for T1, T2, T3, T4 and T5, respectively. There was no a marked statistical difference $(\mathrm{P}<0.05)$ in edible carcass yield a diet containing DBRCM compared with the control group. The edible carcass yield on each sexes was not influenced $(\mathrm{P}>0.05)$ by the inclusion level of dried blood rumen content mixture. The dressing percentage of the edible carcass yield ranged from $63.1 \%$ - 66.6\%. Statistically, there was no any influence 
$(\mathrm{P}>0.05)$ in dietary treatment groups. Sex didn't affect $(\mathrm{P}>0.05)$ slaughter weight, edible carcass yield and dressing percentage when birds fed a diet containing dried blood rumen content mixture.

The commercial carcass weight was 937.4g (T1), 984.7g (T2), 962.0g (T3), 925.0g (T4) and

833.1g (T5) and there was no a statistical difference $(\mathrm{P}<0.05)$ among the treatment groups.

The dressing percentage based on the commercial carcass weight ranged $53.7 \%-56.6 \%$ and no a marked statistical difference among the treatment groups. The commercial carcass yield and dressing percentage were not affected $(\mathrm{P}>0.05)$ by sex when birds fed the five dietary treatment groups. Birds fed up to $80 \%$ DBRCM there were no a statistical marked significant difference $(\mathrm{P}>0.05)$ in the commercial carcasses components such as thigh, thigh percentage, drumstick, drumstick percentage, breast, breast percentage, back, back percentage, wing and wing percentage. However, drumstick and its percentage, breast percentage, wing and its percentage were significantly influenced $(\mathrm{P}<0.05)$ by sex. Males were higher $(\mathrm{p}<0.05)$ in drumstick, drumstick percentage, wing and wing percentage than females. Breast percentage in females was higher $(\mathrm{P}<0.05)$ than that of males. There was no a significant difference $(\mathrm{P}>0.05)$ in abdominal fat weight, abdominal fat percentage, giblet weight and giblet percentage among treatment groups in this experimental period. However, abdominal fat and abdominal fat percentage were significantly influenced $(\mathrm{P}<0.05)$ by sex. Females were higher $(\mathrm{P}<0.05)$ abdominal and abdominal fat percentage than males. There was no a statistical difference $(\mathrm{P}>0.05)$ in the total nonedible offal (TNEO), TNEO\%, total edible offal (TEO) and TEO\%. On the other hand the total nonedible offal was affected by sex and males were higher than that of females. However, numerically birds fed at 80\%DBRCM (T5) almost had the lowest component among other treatment groups.

Table 4. Carcass characteristics of SASSO C44 broiler chicks (1-56 days) fed different level of dried bovine blood rumen content mixture as a replacement for soya bean meal

\begin{tabular}{|c|c|c|c|c|c|c|c|c|c|c|}
\hline \multirow[t]{2}{*}{ Parameters } & \multicolumn{10}{|c|}{ Experimental Diets } \\
\hline & T1 & $\mathrm{T} 2$ & T3 & T4 & T5 & SEM & $\mathbf{P}$ & $\mathbf{M}$ & $\mathbf{F}$ & $\mathbf{P}$ \\
\hline $\begin{array}{l}\text { Slaughter } \\
\text { weight(g) }\end{array}$ & 1707.5 & 1736.7 & 1736.8 & 1719.9 & 1550.2 & 31.839 & 0.311 & 1731.5 & 1648.9 & 0.0721 \\
\hline $\begin{array}{c}\text { Plucked } \\
\text { weight(g) }\end{array}$ & 1507.1 & 1516.8 & 1540.8 & 1520.8 & 1378.2 & 27.582 & 0.380 & 1532.8 & 1452.8 & 0.0597 \\
\hline $\begin{array}{c}\text { Plucked } \\
\text { weight (\%) }\end{array}$ & 88.2 & 87.4 & 88.7 & 88.4 & 89.1 & 0.255 & 0.291 & 88.6 & 88.2 & 0.3961 \\
\hline $\begin{array}{c}\text { Commercial } \\
\text { carcass } \\
\text { weight(g) }\end{array}$ & 937.4 & 984.7 & 962.0 & 925.0 & 833.1 & 22.775 & 0.281 & 957.9 & 899.0 & 0.0956 \\
\hline *Dressing \% & 54.9 & 56.6 & 55.3 & 53.7 & 53.7 & 0.6741 & 0.698 & 55.2 & 54.5 & 0.6129 \\
\hline $\begin{array}{c}\text { Edible carcass } \\
\text { yield(g) }\end{array}$ & 1091.6 & 1159.3 & 1135.5 & 1104.7 & 977.9 & 26.290 & 0.226 & 1124.4 & 1063.2 & 0.1209 \\
\hline **Dressing \% & 63.9 & 66.6 & 65.4 & 64.2 & 63.1 & 0.651 & 0.533 & 64.8 & 64.5 & 0.8269 \\
\hline
\end{tabular}




\begin{tabular}{ccccccccccc}
\hline Thigh(g) & 191.3 & 194.4 & 186.2 & 185.9 & 171.3 & 4.233 & 0.533 & 190.0 & 181.6 & 0.2724 \\
Thigh\% & 11.2 & 11.2 & 10.7 & 10.8 & 11.0 & 0.148 & 0.816 & 11.0 & 11.0 & 0.8152 \\
Drumstick(g) & 174.3 & 177.2 & 171.0 & 168.5 & 150.9 & 4.082 & 0.292 & $180.5^{\mathrm{a}}$ & $156.2^{\mathrm{b}}$ & 0.0052 \\
Drumstick\% & 10.2 & 10.2 & 9.8 & 9.8 & 9.7 & 0.158 & 0.791 & $10.4^{\mathrm{a}}$ & $9.5^{\mathrm{b}}$ & 0.0092 \\
Breast(g) & 280.1 & 305.8 & 301.9 & 274.2 & 244.6 & 8.833 & 0.172 & 274.8 & 287.8 & 0.2873 \\
Breast\% & 16.4 & 17.6 & 17.5 & 16.0 & 15.8 & 0.372 & 0.453 & $15.9^{\mathrm{b}}$ & $17.5^{\mathrm{a}}$ & 0.0138 \\
Back(g) & 153.8 & 154.4 & 153.7 & 151.9 & 135.1 & 3.990 & 0.546 & 155.4 & 144.1 & 0.0825 \\
Back\% & 9.0 & 8.9 & 8.8 & 8.8 & 8.7 & 0.121 & 0.972 & 8.9 & 8.7 & 0.4363 \\
Wing(g) & 138.0 & 153.0 & 149.2 & 144.7 & 131.3 & 4.140 & 0.531 & $157.2^{\mathrm{a}}$ & $129.3^{\mathrm{b}}$ & 0.0008 \\
Wing\% & 8.1 & 8.8 & 8.5 & 8.4 & 8.5 & 0.136 & 0.627 & $9.0^{\mathrm{a}}$ & $7.8^{\mathrm{b}}$ & 0.0005 \\
Abdominal & 18.9 & 23.2 & 16.4 & 17.7 & 17.1 & 1.106 & 0.327 & $16.1^{\mathrm{b}}$ & $21.2^{\mathrm{a}}$ & 0.0081 \\
fat(g) & & & & & & & & & & \\
Abdominal & 1.1 & 1.3 & 1.2 & 1.1 & 1.1 & 0.060 & 0.528 & $0.9^{\mathrm{b}}$ & $1.3^{\mathrm{a}}$ & 0.0019 \\
fat\% & & & & & & & & & & \\
Giblet & 93.2 & 102.9 & 107.1 & 107.6 & 91.4 & 2.859 & 0.0592 & 101.5 & 99.4 & 0.6124 \\
weight(g) & & & & & & & & & & \\
Giblet \% & 5.5 & 5.9 & 6.2 & 6.2 & 5.9 & 0.097 & 0.0652 & 5.8 & 6.0 & 0.0567 \\
TNEO & 497.0 & 525.8 & 506.0 & 500.5 & 431.3 & 12.526 & 0.1440 & $511.7^{\mathrm{a}}$ & $465.4^{\mathrm{b}}$ & 0.0481 \\
TNEO\% & 29.2 & 30.2 & 29.2 & 29.1 & 27.8 & 0.417 & 0.5751 & 29.5 & 28.2 & 0.4361 \\
TEO & 154.2 & 174.8 & 173.7 & 179.7 & 144.9 & 5.1871 & 0.1282 & 166.6 & 164.3 & 0.7305 \\
TEO\% & 9.1 & 10.0 & 10.0 & 10.4 & 9.3 & 0.1852 & 0.0871 & 9.6 & 9.9 & 0.2478 \\
\hline
\end{tabular}

Means with a different superscript in a row are significantly different $(P<0.05) ; g$-gram;

T1-0\%DBRCM+100\%SBM Roasted; T2-20\% DBRCM +80\%SBM Roasted; T3 40\%

DBRCM +60\%SBM Roasted; T4-60\% DBRCM + 40\% SBM Roasted; T5-80\%

DBRCM+20\%SBM Roasted; SEM-Standard Error of the Mean;M-Male;F-Female;TNEOtotal nonedible offal, TEO = total edible offal, *= Dressing $\%$ calculated on the basis of commercially used (Eviscerated) carcass, **=Dressing\% calculated by including edible offal (skin, gizzard and liver)

\section{Disscusions}

\section{Slaughter weight}

Birds had not shown a statistical significant difference $(\mathrm{P}>0.05)$ in slaughter weight among the treatment groups. Sexes also not significantly affected $(\mathrm{P}>0.05)$ by receiving DBRCM in slaughter weight. Numerically males are heavier than females. The result confirmed the report of Faria et al., (2010) who reported that higher slaughter weight and carcass weight in males are related to their higher muscle development as influenced by the production of androgen hormone. The result is in line with the report of Asrat (2007) who indicated that the difference between male and females might be the feed intake of males higher than that of female and sex hormones in the female favours fat deposition and adipose tissues are less dense than muscle tissues. Donald and William, (2002) indicated that males grow more quickly and efficiently than females.

\section{Commercial carcass weight}

The commercial carcass which include two wings, two thighs, two drumsticks, back, and breast collectively referred to as a carcass weight (Asrat, 2007). Consumers prefer chickens with high yield of noble parts, such as breast, drumsticks, and thighs (Faria et al., 2010). Birds fed a diet 
containing DBRCM has not shown a significant difference $(\mathrm{P}>0.05)$ in carcass weight among the treatment groups. The carcass weight was not influenced by sex when birds fed the dietary treatment groups. Similar study was observed by Steven and John, (2008) who noted that comparable weights of male and female birds have similar yields of carcass portions.

\section{Dressing percentage}

Dressing \% was calculated based on the commercial carcass weight (excluding the total edible offal (TEO). Birds fed different levels of DBRCM had not shown a marked statistical significant difference $(\mathrm{P}>0.05)$ among the treatment groups. Significantly, sex had no any influence $(\mathrm{P}>0.05)$ in dressing percentage by the inclusion of DRCM in the diet. This result is in line with Steven and John, (2008) who reported that the dressing percentage of female and male had no a marked significant difference $(\mathrm{P}>0.05)$ in dressing percentage. The same result was observed by Engku et al., (2007) who reported that there was no any statistical difference $(P>0.05)$ in the dressing percentage of males and females. Probably the slaughter weight of males and females were nearly comparable this might be had statistically similar dressing percentage. The result is confirmed by Steven and John, (2008) who noted that comparable weights of male and female birds have similar yields of carcass portions and it may have similar dressing percentage.

\section{Edible carcass yield}

In Ethiopia the edible carcass portions were calculated by adding the total edible offal to commercially important carcass components like back, wing, drumsticks, thighs and breast. There was no a statistical significant difference $(\mathrm{P}>0.05)$ in edible carcass yield when birds fed different dietary treatment groups. The result confirmed that the report of Onu et al, (2011) who noted that there was no significant $(P>0.05)$ differences existed in the carcass characteristics of the birds fed BBRCM and had no adverse effect on the carcass yield and organ weights of the birds. The same result was observed by Esonu et al (2011) who reported that there was no significant differences $(\mathrm{P}>0.05)$ in the live weight and dressing percentage of birds fed on different levels of FBBRD. However different report was observed by Olukayode et al., (2008) who reported that there was a statistical significant difference $(p<0.05)$ in carcass yields which received SDRBM compared with $0 \%$ SDRBM diet. Edible carcass yield was not significantly influenced by sex. Whereas the edible carcass meat of males numerically higher than that of females. This result was confirmed by Steven and John, (2008) who noted that the yield of edible meat of females may be less than for the males if both are fed the same diet. 


\section{Dressing percentage}

In the edible carcass; gizzard, liver and skin were considered as part of the edible carcass yield, therefore, a higher dressing percentage was recorded when it was calculated by considering them. Birds fed different dietary treatment groups had not shown a significant difference $(\mathrm{P}>0.05)$ in dressing percentage. The result is in line with the report of Onu et al, (2011) who confirmed that there was no significant differences $(P>0.05)$ existed in the dressing percentage of the birds fed bovine blood rumen content mixture (BBRCM) and had no adverse effect on the carcass yield. Esonu et al., (2011) also confirmed that there was no significant differences $(\mathrm{P}>0.05)$ in the live weight and dressing percentage of birds fed on different levels of fermented bovine blood rumen digesta (FBBRD). However different result was observed by Olukayode et al., (2008) who reported that there was a statistical significant difference $(p<0.05)$ in dressing percentage which received SDRBM compared with $0 \%$ sun dried rumen blood meal (SDRBM).

\section{Total edible offal (TEO) and its percentage}

Under the Ethiopian context total edible offal includes skin, gizzard and liver. Birds fed the inclusion of DBRCM up 80\% has not shown a statistical significant difference $(\mathrm{P}>)$ in TEO. TEO was not influenced by sex which fed different dietary treatment groups. The total edible offal percentage was not statistically influenced by the dietary treatment groups. Both males and females of TEO\% was not significantly affected ( $P>0.05)$ by a diet containing DBRCM. The same result was reported by Onu et al., (2011) who reported that the organ weight of birds were not significantly influenced $(\mathrm{P}>0.05)$ by the addition of BBRCM in broiler diets. The result was supported by Okorie (2005) who noted that there were no significant differences $(\mathrm{P}>0.05)$ in organ weights among birds that were given dried rumen content.

\section{Total nonedible offal (TNEO) and its percentage}

In Ethiopia, the total nonedible offal components include blood, shank \& claws, feather, head, crop, oesophagus, proventriculus, spleen, pancreas, kidney, heart, lung, small intestine, large intestines and abdominal fat. There was no a significant different $(\mathrm{P}>0.05)$ in TNEO when birds fed the dietary treatment groups, however the TNEO was influenced $(\mathrm{P}<0.05)$ by sex. Males had significantly higher TNEO than females. This result agreed with Steven and John, (2008) who noted that the yield of edible meat of females may be less than for the males if both are fed the same diet. Probably this indicates that the total nonedible offal also lower in females than males. 
TNEO\% were not significantly $(\mathrm{P}>0.05)$ affected by a diet containing DBRCM and by sex.

\section{Abdominal fat}

There was no any influence $(\mathrm{P}>0.05)$ in the abdominal fat and abdominal fat percentage when birds fed different levels dietary treatment groups. However, a significant difference was observed by sex. Females had higher abdominal fat and abdominal fat percentage than males. The result was in line with the report of Steven and John, (2008) who confirmed that the female broiler tends to deposit more fat than the male broiler. The same result was reported by Melese et al., (2013). This is always true, in the same age and feeding program, female birds are fatter than males because female hormones stimulate fat deposition (Scanes et al., 2004).

\section{Breast meat}

The success of poultry meat production has been strongly related to improvements in growth and carcass yield, mainly by increasing breast proportion and reducing abdominal fat (Musa et al., 2006). Breast meat is the most liked meat from the commercial carcass components for its low fat content and faster rate accumulation of muscle tissues by birds than other parts. Breast meat was not significantly influenced $(\mathrm{P}>0.05)$ when birds fed a diet containing DBRCM compared with the control group. However, it was significantly influenced $(\mathrm{P}<0.05)$ by sex. Females had higher $(\mathrm{P}<0.05)$ breast meat than meals. This result was in line with the report of Musa et al., (2006) who reported that female broilers had greater breast meat compared with male broilers. Similar result was reported by Steven and John, (2008) who confirmed that the female birds had higher $(\mathrm{P}<0.05)$ breast meat than males. The result also coincides with the report of Faria et al., (2010) who noted that females have higher breast yield than males, and males have higher thighs yield than females.

\section{Giblet weight and its percentage}

The weight of giblets (liver, heart and gizzard) was not significantly affected $(\mathrm{P}>0.05)$ by the diet containing dried blood rumen content mixture compared with the control groups. The individual components of the giblet such as the liver, heart and gizzard had not shown a marked statistical difference $(\mathrm{P}>0.05)$ among the dietary treatment groups. The result is confirmed by the report of Onu et al., (2011) who noted that the giblet weight and its components were not significantly influenced by a diet containing BBRCM. The giblet percentage in this study ranged from $5.5 \%$ to $6.2 \%$ and there was no a statistical difference $(\mathrm{P}>0.05)$ among the groups. Nearly similar result was observed by Onu et al., (2011) who reported that 
the giblet percentage ranged from $6.6 \%$ to $7.4 \%$ and there was no any significant difference $(\mathrm{P}>0.05)$ among the treatment groups when birds fed BBRCM.

In general, most of the carcass characteristics of birds were not significantly $(\mathrm{P}>0.05)$ affected by the diet containing DBRCM up to $80 \%$ substitution level. The addition of DBRCM in the diet has not brought a significant difference $(\mathrm{P}>0.05)$ in several carcass characteristics on male and female birds. The result confirmed that the report of Onu et al, (2011) who noted that there was no significant $(\mathrm{P}>0.05)$ differences existed in the carcass characteristics of the birds fed BBRCM and had no adverse effect on the carcass yield and organ weights of the birds. The same result was observed by Esonu et al (2011) who reported that there was no significant differences $(\mathrm{P}>0.05)$ in the live weight and dressing percentage of birds fed on different levels of FBBRD. However, different report was observed by Olukayode et al., (2008) who reported that there was a statistical significant difference $(\mathrm{p}<0.05)$ in carcass yields which received SDRBM compared with $0 \%$ SDRBM.

\section{Conclusion}

From this experiment it could be concluded that the replacement of dried blood rumen content mixture up to $80 \%$ substitution level to soybean meal is paramount important to produce edible carcass with in the cheapest cost. Therefore there is no any deleterious effect on carcass characteristics

\section{Recommendations}

The collection and the processing method is manually, so to save time and cost it should be collected and processed mechanically

Technology dissemination about the benefit of this feed stuff is very advisable especially for small-scale, medium-scale and large scale commercial poultry producers to reduce their production cost.

Further research is needed to know the effect of this feed staff beyond $80 \%$ substitution level on carcass characteristics of broiler chicks.

\section{Acknowledgment}

The author is especially acknowledged to Debre Markos University for its permission and financial support to study my $\mathrm{PhD}$. Besides, I would like to thank College of Veterinary Medicine and Agriculture, Addis Ababa University for providing me with a good environment and facilitates to complete this $\mathrm{PhD}$ program. 


\section{References:}

Adeniji, A. A. and Jimoh, A. (2007): Effects of Replacing Maize with Enzyme- Supplemented Bovine Rumen Content in the Diets of Pullet Chicks. International Journal of Poultry Science. 6 (11): 814-817

Asrat Tera Delebo, (2007). Assessment the Impact of Feeding Fish Meal Prepared at Small Scale Level on Feed Intake, Growth And Carcass Traits of Rhode Island Red Chicks. MSc thesis summited to Hawassa University, Awassa, Ethiopia. pp 74-84.

Bisrat Gebremichael Urgessa,(2013): Defect Assessment of Ethiopian Hide and Skin: The Case of Tanneries in Addis Ababa and Modjo, Ethiopia, Ethiopian Leather Industry Development Institute (LIDI), Addis Ababa, Ethiopia . Global Veterinaria 11 (4): 395-398

CSA (Central Statistical Agency) (2013): Livestock Statistics 2013. CSA, Federal Democratic Republic of Ethiopia, Addis Ababa, Ethiopia

Dominguez-Bello, M.G., Michelangeli, F., Ruis, M.C., Garcia, A., Rodriguez, E., (1994): Ecology of The Folivorous Hoatzin (Opisthocomus hoazin) On The Venezuelan Plains. The Auk 111 (3), 643-651

Donald, D.B. and D.W. William (editors). 2002. Commercial Chicken Meat and Egg Production. 5thed. Kluwer Academic Publishers. USA. pp 224-226. Downes T.E.H., Nourse L.D., Siebrits F.K. Hastings J.W. (1987): The relative nutritive value of irradiated spray-dried blood powder and heatsterilized blood meal as measured in combination with whey protein. S.Afr.J.Anim.sci.17(2):55-58

Engku Azahan E.A., Marini A.M. and Noraziah M (2007): Evaluation on the effects of sex on growth and carcass characteristics of broilers, Kuala Lumpur, Malaysia. J. Trop. Agric. and Fd. Sc. 35(2): 313- 318

Esonu, B. O; Azubuike, J. C; Udedibie, A. B. I; Emenalom, O. O; Iwuji, T. C and Odoemenam, V (2011): Evaluation of the Nutritive Value of Mixture of Fermented Bovine Blood and Rumen Digesta for Broiler Finisher Journal of Natural Sciences Research 1(4):65-71.

Etalem Tesfaye, Getachew Animut, Mengistu Urge and Tadelle Dessie (2013): Moringa olifera Leaf Meal as an Alternative Protein Feed Ingredient in Broiler Ration. International Journal of Poultry Science 12 (5): 289-297. FAO (2013): Global Poultry Trends- the poultry site. pp 1-7

Faria PB., Bressan MC., Souza XR de., Rossato LV., Botega LMG., Gama LT da., (2010): Carcass and Parts Yield of Broilers Reared Under a SemiExtensive System. Brazilian Journal of Poultry Science, 12 (3): 153 - 159 Liu, D.C. (2009): Better Utilization of By-Products from the Meat Industry. Department of Animal Science. National Chung-Hising University Taichung Taiwan Roc.www.agnet.org/library/teb/515/eb/515.pdf Retrieved on 4/11/2009. 
Martinez WS (1999): Vertical coordination in the pork and broiler industries: implications for pork and chicken products. Agricultural Economic Report No 777, U.S. Department of Agriculture, Washington D.C.

Melesse A., Dotamo E., Banerjee S., Berihun K. and Beyan M.(2013): Studies on Carcass Traits, Nutrient Retention and Utilization of Koekoeck Chickens Fed Diets Containing Different Protein Levels with Iso-Caloric Ration. J Anim Sci Adv 2013, 3(10): 532-543

Melkamu B.Y. (2013): The effect of feeding different levels of dried tomato pomace on the performance of Rhode Island Red (RIR) grower chicks. International Journal of Livestock Production, 4(3): 35-41.

Musa H.H, Chen G.H, Cheng J.H., Li B.C. and. Mekki D.M.(2006): Study on Carcass Characteristics of Chicken Breeds Raised under the Intensive Condition. International Journal of Poultry Science 5 (6): 530-533

Negussie Dana, (1999): On-Farm Evaluation of Rhode Island Red (RIR) and Local Chickens under Different Management Regimes in the Highland Of Ethiopia. MSc Thesis, Department of Animal Nutrition and Management, SLU, Sweden.

Okorie, K. C. (2005): The effects of dried pulverized rumen content on the performance, carcass and organ characteristics of broiler finisher. Anim. Prod. Res. Adv. 2: 96-100

Olukayode M., Babafunso S. and Segun A. (2008): Conversion of Abattoir Wastes Into Livestock Feed: Chemical Composition of Sun-Dried Rumen Content Blood Meal And Its Effect on Performance of Broiler Chickens, Conference on International Research on Food Security, Natural Resource Management and Rural Development University of Hohenheim, Nigeria.

Onu P.N., Otuma M.O., Odukwe C.A. and Aniebo A. O. (2011): Effects of Different Levels of Bovine Blood / Rumen Content Mixture on Productive Performance, Carcass Characteristics and Economics of Production of Finisher Broilers. International Journal of Food, Agriculture and Veterinary Sciences : 1 (1): 10-16.

Onu, P. N. (2007): The Influence of Heat- Treated Sheep Manure on the Performance, Carcass Characteristics and Economics of Production of Starter Broilers. Journal of Animal and Veterinary Advances 6(11): 13231327

SAS (Statistical Analysis Systems, Version 9.2), 2008. Statistical Analysis Systems for mixed models. SAS Institute Inc, Cary, NC, USA.

SASSO C44 Broiler Breeds: http://www.sasso.fr/best-chicken-breedsalternative-growth-for-free-range-poultry-breeding.html, retrieved on 20/03/ 2016).

Scanes, C.G., G. Brant and M.E. Ensminger. (2004): Poultry Science. 4th ed. Pearson Prentice Hall. New Jersey. pp: 105-106 
SPSS, (2012): Statistical Package for Social Science, SPSS 20 for Windows. SPSS Inc. Chicago, Illinois

Steven Leeson and John D. Summers (2008): Commercial Poultry Nutrition Third Edition, Published By Nottingham University Press, England. PP 230289

Wijnands J.H.M, Napol Dufera,Lute J.C.M,Van Loo E.N.,(2011): Ethiopian Soybean and Sunflower Value Chains: Opportunities and Challenge, Addis Ababa ,Ethiopia, pp1-20 